\title{
Therapeutic use of the Arts for Patients with Multiple Sclerosis
}

\author{
Lisa M Gallagher ${ }^{1}$ and Francois Bethoux ${ }^{1,2}$ \\ 1. Cleveland Clinic, Arts and Medicine Institute, Cleveland OH, US; 2. Cleveland Clinic, Neurological Institute, Cleveland OH, US
}

DOl: https://doi.org/10.17925/USN.2017.13.02.82

\section{Keywords}

Music therapy, art therapy, dance therapy, multiple sclerosis

Disclosure: Lisa Gallagher and Francois Bethoux have nothing to disclose in relation to this article. No funding was received in the publication of this article.

Compliance with Ethics: This article involves a review of the literature and did not involve any studies with human or animal subjects performed by any of the authors.

Authorship: All named authors meet the International Committee of Medical Journal Editors (ICMJE) criteria for authorship of this manuscript, take responsibility for the integrity of the work as a whole, and have given final approval to the version to be published.

Open Access: This article is published under the Creative Commons Attribution Noncommercial License, which permits any noncommercial use, distribution, adaptation, and reproduction provided the original author(s) and source are given appropriate credit.

Received: June 3, 2017

Accepted: July 17, 2017

Citation: US Neurology, 2017;13(2):82-9

Corresponding Author: Lisa M Gallagher, Cleveland Clinic Arts \& Medicine Institute, 1950 Richmond Rd/TR308, Lyndhurst, OH 44124, US. E: gallag|@ccf.org
Multiple sclerosis (MS) is a chronic neurological disorder which causes demyelination and axonal damage in the central nervous system (CNS), leading to various neurological impairments and worsening disability over time in a majority of affected individuals. MS is presumed to be an autoimmune disease, although its cause remains unknown. ${ }^{1}$ The direct and indirect consequences of MS often negatively impact activities, participation, and quality of life; and may lead to a loss of functional independence. In addition, comorbidities such as depression are frequently associated with MS. ${ }^{2}$ The comprehensive management of MS includes disease-modifying therapies, symptom management, rehabilitation, and lifestyle changes to optimize wellness. ${ }^{3}$ Patient empowerment and promotion of self-efficacy are important strategies in the management of MS. Individuals with MS have been encouraged to utilize coping strategies that are problem-focused and provide a sense of control. ${ }^{4}$ It has been found that interacting with others and engaging in leisure activities can improve mental and physical health in individuals with $\mathrm{MS}^{5}$

A large number of people with MS have expressed interest in using complementary and alternative therapies (CAT), including yoga, mindfulness, stress management exercises, acupuncture, meditation, and journaling, among many others. ${ }^{5-12}$ Indeed, in one survey, $84 \%$ of respondents reported using at least one CAT modality in the past year. ${ }^{13}$ Therapeutic arts constitute a group of CAT modalities which have been seldom investigated in MS. ${ }^{14}$

\section{Therapeutic arts and multiple sclerosis}

Using the arts for therapeutic purposes is not a new idea. Philosophers in ancient Greece referred to the healing power of music, and for Plato: "Man's music is seen as a means of restoring the soul, as well as confused and discordant bodily afflictions, to the harmonic proportions that it shares with the world soul of the cosmos." (Timaeus, 429-347 BC). More recently, publications directed to a general audience, such as Dr. Oliver Sacks' Musicophilia: Tales of Music and the Brain, have highlighted the potential benefits of music in individuals with various medical conditions, including neurological disorders. ${ }^{15}$ Therapeutic uses of the arts can take many forms and involve a variety of professionals. We will mostly limit our discussion to therapeutic art disciplines including art therapy (AT), dance/ movement therapy (D/MT), and music therapy (MT). These therapies are performed by individuals with degrees and specialized training in these areas, and who are registered or certified.

The American Art Therapy Association (AATA) defines AT as "an integrative mental health profession that combines knowledge and understanding of human development and psychological theories and techniques with visual arts and the creative process to provide a unique approach 
Table 1: Studies about art and multiple sclerosis

\begin{tabular}{|c|c|c|c|c|c|c|c|}
\hline Publication & Intervention & $\begin{array}{l}\text { Type of study/ } \\
\text { article }\end{array}$ & $\begin{array}{l}\text { Setting/ } \\
\text { population }\end{array}$ & $\begin{array}{l}\text { Demographic } \\
\text { and MS } \\
\text { information }\end{array}$ & $\begin{array}{l}\text { Session } \\
\text { number/length }\end{array}$ & $\begin{array}{l}\text { Outcome measures - change } \\
\text { (when applicable) }\end{array}$ & Summary of findings \\
\hline $\begin{array}{l}\text { Fraser and } \\
\text { Keating } 5 \\
\text { (2014) }\end{array}$ & Art & $\begin{array}{l}\text { Uncontrolled } \\
\text { pilot study } \\
(n=14)\end{array}$ & $\begin{array}{l}\text { Creative art } \\
\text { program }\end{array}$ & $\begin{array}{l}14 \text { F, } 0 \text { M; age } \\
\text { range 29-70 } \\
\text { years (average } \\
51.3 \text { years); no } \\
\text { information on } \\
\text { MS subtype or } \\
\text { disability }\end{array}$ & $\begin{array}{l}\text { One 2-hour } \\
\text { session weekly } \\
\text { for } 4 \text { weeks }\end{array}$ & $\begin{array}{l}\text { Rosenberg Self-Esteem Scale } \\
\text { - significant improvement } \\
(\mathrm{p}=0.009) \\
\text { Modified Social Support Survey } \\
\text { - significant improvement } \\
(\mathrm{p}=0.046) \\
\text { MS Self-Efficacy Scale - } \\
\text { significant improvement of self- } \\
\text { efficacy to control MS ( } \mathrm{p}=0.007) \\
\text { and to function with MS ( } \mathrm{p}=0.019) \\
\text { Herth Hope Index - significant } \\
\text { improvement }(p=0.002)\end{array}$ & $\begin{array}{l}\text { Art program was effective; had } \\
\text { potential to improve lives of } \\
\text { patients with MS; and had positive } \\
\text { impact on social support, self- } \\
\text { efficacy, self-esteem, and hope. }\end{array}$ \\
\hline $\begin{array}{l}\text { Hunt, et al. }{ }^{23} \\
\text { (2014) }\end{array}$ & Art & $\begin{array}{l}\text { Qualitative } \\
\text { interviews } \\
(n=5)\end{array}$ & $\begin{array}{l}\text { Physiotherapy } \\
\text { clinic }\end{array}$ & $\begin{array}{l}3 \text { F, } 2 \text { M; age } \\
\text { range 40-65 } \\
\text { years; time since } \\
\text { MS diagnosis, } \\
\text { range 1-30 } \\
\text { years }\end{array}$ & $\begin{array}{l}\text { N/A: indivi- } \\
\text { duals partici- } \\
\text { pated in visual } \\
\text { arts as leisure } \\
\text { activity, not } \\
\text { in art therapy } \\
\text { sessions }\end{array}$ & Semi-structured interviews & $\begin{array}{l}\text { Art-making helped with opening } \\
\text { new doors, coping with functional } \\
\text { losses, identity maintenance, } \\
\text { emotional well-being, self-worth, } \\
\text { life satisfaction, using time } \\
\text { well, filling occupational voids, } \\
\text { decreasing worry about illness, } \\
\text { learning, development, and social } \\
\text { camaraderie. }\end{array}$ \\
\hline $\begin{array}{l}\text { Kelly } \\
\text { (2009) }\end{array}$ & Art & $\begin{array}{l}\text { Case study } \\
(n=1)\end{array}$ & $\begin{array}{l}\text { Family health } \\
\text { practice }\end{array}$ & $\begin{array}{l}1 \mathrm{~F} ; 51 \text {-years- } \\
\text { old; newly } \\
\text { diagnosed with } \\
\text { MS }\end{array}$ & Not reported & N/A & $\begin{array}{l}\text { Art was an outlet to decrease } \\
\text { stress, describe vision problems } \\
\text { to physicians, describe emotions, } \\
\text { change view on life, change } \\
\text { relationships, and cope with illness. }\end{array}$ \\
\hline $\begin{array}{l}\text { Sutherland }{ }^{24} \\
\text { (1999) }\end{array}$ & AT & $\begin{array}{l}\text { Case study } \\
(n=1)\end{array}$ & $\begin{array}{l}\text { Female } \\
\text { geriatric ward } \\
\text { at veteran's } \\
\text { hospital }\end{array}$ & $\begin{array}{l}\text { 1 F; 63-years- } \\
\text { old; chronic } \\
\text { progressive MS } \\
\text { with paraplegia } \\
\text { and left upper } \\
\text { monoplegia }\end{array}$ & $\begin{array}{l}28 \text { sessions } \\
\text { over } 9 \text { months }\end{array}$ & N/A & $\begin{array}{l}\text { Rich symbolism found in paintings, } \\
\text { but patient refused to discuss. } \\
\text { Therefore, art therapist suggested } \\
\text { interpretations and themes such } \\
\text { as cancer, death, anger regarding } \\
\text { illness, integration of feminine and } \\
\text { masculine parts of personality, and } \\
\text { termination of relationship with AT. }\end{array}$ \\
\hline $\begin{array}{l}\text { Field } 25 \\
(1976)\end{array}$ & AT & $\begin{array}{l}\text { Case study } \\
(n=1)\end{array}$ & $\begin{array}{l}\text { Neurological } \\
\text { hospital }\end{array}$ & $\begin{array}{l}1 \mathrm{M} ; 60 \text {-years- } \\
\text { old; "almost } \\
\text { totally paralyzed } \\
\text { by MS" }\end{array}$ & $\begin{array}{l}\text { One 2-hour } \\
\text { session weekly } \\
\text { for almost } 2 \\
\text { years }\end{array}$ & N/A & $\begin{array}{l}\text { Improved emotional expression; } \\
\text { increased self-esteem; gratification } \\
\text { through art; and recovery of the } \\
\text { use of impaired limbs. }\end{array}$ \\
\hline
\end{tabular}

$A T=$ art therapy with intervention of an art therapist; $F=$ female; $M=$ male; $M S=$ multiple sclerosis; $N / A=$ not applicable. 'Significant' refers to statistical significance.

for helping clients improve psychological health, cognitive abilities, and sensory-motor functions".16 Through the use of various art media and verbal processing, art therapists seek to enable communication with the ultimate goal of providing help with emotional and behavioral issues. D/MT is defined by the American Dance Therapy Association (ADTA) as "a psychotherapeutic approach that uses movement to encourage the cognitive, social, physical, and emotional integration of the patient". ${ }^{17}$ With $\mathrm{D} / \mathrm{MT}$, the focus is on expression through body movement. According to the American Music Therapy Association, MT is the clinical and evidencebased use of music interventions to accomplish individualized goals within a therapeutic relationship by a credentialed professional who has completed an approved MT program. ${ }^{18}$ While they differ in the art form used, therapeutic art disciplines share a strong focus on generating and sharing emotions, and generally include a motor activity component. The interventions can be implemented one-on-one, or in a group setting.
In 2013 the National Multiple Sclerosis Society conducted a survey among close to 200 individuals with MS on their use of the arts. ${ }^{19}$ Artsrelated activities included visual arts for $55 \%$ of respondents, music for $46 \%$, and writing for $45 \%$. Most respondents were involved with their current creative activity before being diagnosed with MS, and over one half of those found a way to continue pursuing this activity through adaptations. ${ }^{19,20}$ Reported benefits included taking their mind of their disease, channeling emotions, and promoting a sense of control and self-esteem. Anecdotally, individuals with MS who engaged in art-related activities have consistently reported emotional benefits, and sometimes improvement of cognition and motor control. ${ }^{20,21}$

The goals of this narrative review are to increase awareness of therapeutic art use in MS patients, to summarize key evidence regarding the effects of therapeutic arts in this population, and to assess the need for further research. 


\section{Art therapy}

We found a few studies and informational articles regarding the use of art and art therapy with individuals with MS (Table 1). Kelly wrote a case report about a newly diagnosed patient with MS who experienced depression and anxiety, and was advised to find strategies for stress relief. The patient, who was an artist, chose to create pieces of art to describe the vision problems she was having, to her physicians, as well as to describe her emotions. The art became an outlet for her, and she found that it helped her change her view on life, and identify ways to cope with her illness and not let it overwhelm her. ${ }^{22}$

The meaning of participating in leisure-based visual art-making for individuals with MS was explored in a qualitative study in Ireland. ${ }^{23}$ Semistructured interviews were conducted among five adults (three women). Participants found that art-making helped to decrease worrying about MS and to maintain self-identity, filled time and "occupational voids" left by lifestyle changes, helped in dealing with decreased functional abilities; and improved life satisfaction, self-worth, and emotional well-being. The positive effects of art classes were also emphasized.

A case study reported the use of painting in the setting of AT for a 63-yearold woman with chronic progressive MS who was paraplegic with upper left monoplegia, leaving her with only one functional limb.24 There was a lot of symbolism in her paintings, but she often refused to discuss their meanings; therefore, the art therapist suggested interpretations and themes such as cancer, death, anger regarding her illness, integration of feminine and masculine parts of personality, and termination of relationship with the art therapist.

Field, an art therapist, reported on her work with patients diagnosed with a variety of neurological disorders, including MS. The AT goals in this group of patients were to help them more effectively use their bodies; to improve their motor function; and to improve their emotional issues, particularly guilt, fear, depression, and anxiety; while providing them with art experiences that were enjoyable and rewarding. ${ }^{25}$

In a case series involving 12 individuals with MS who participated in eight 2-hour weekly sessions of AT, Stutsman et al. found that both the creative process and the group activity generated positive outcomes. ${ }^{26}$ Participants reported increased focus on the positive aspects of life, as well as improved depressive symptoms and self-esteem. The team comprised an art therapist, a counselor, and an occupational therapist.

Fraser and Keating conducted a 4-week creative art program that utilized a specific art form each week including beading, collage-making, knitting, and watercolor. ${ }^{5}$ The program was facilitated by a nurse and creative artists, and there were 14 women with MS in attendance. At the end of the program, there was a statistically significant improvement on the Rosenberg Self-Esteem Scale, the Herth Hope Index, the Modified Social Support Survey, and the MS Self-Efficacy Scale. Effect sizes of change were large for hope, self-esteem, and selfefficacy (control subscale).

\section{Dance and movement therapy}

Dance can be seen as a form of physical exercise, but adds components of movement creativity, structured movement, rhythm, and dancing with a partner. D/MT has been shown to have value for patients with neurological disorders such as Parkinson's disease, spinal cord injury, autism, traumatic brain injury, sensory loss, and stroke. ${ }^{27,28}$ The Dance for $\mathrm{PD}^{\circledR}$ program, issued from a collaboration between the Mark Morris Dance Group and the Brooklyn Parkinson Group, offers specialized dance classes to individuals with Parkinson's disease and their care partners in the New York City area, with affiliates in several countries. ${ }^{29}$

Based on this body of evidence, and considering the high prevalence of motor symptoms in MS, it is reasonable to assume that individuals with MS could benefit from participating in dance as a means of improving control over their muscles and body movements. However, there has been very little published research into the use of dance or D/MT with these patients. In fact, at the time this article was written, only two studies were found regarding the use of dance in patients with MS (Table 2).

Salgado and de Paula Vasconcelos published a case study of a 45-year-old woman with relapsing-remitting MS who participated in dance interventions twice a week for over 5 months. ${ }^{30}$ Results from the Minimal Record of Disability (MRD), the Expanded Disability Status Scale (EDSS), and the Scripps Neurological Rating Scale (NRS) reflected decreased neurological impairment after the intervention. Qualitative improvement was noted in emotional states and control of balance, and she did not require as much support to walk safely. After participating in this therapeutic dance intervention, the patient was able to perform activities of daily life that she previously had to limit.

A pilot study was conducted by Mandelbaum et al. in which seven patients with MS participated in a structured salsa dance intervention twice a week for 4 weeks. ${ }^{28}$ Statistically significant improvements were found from baseline to the end of the program on the Dynamic Gait Index (DGI), Timed Up and Go (TUG), Godin Leisure Time Questionnaire, and Activities-specific Balance Confidence Scale. In addition, comparison between baseline and 3-month post-intervention follow-up demonstrated significant improvement on the DGI, TUG, and MS Walking Scale. These findings suggest that MS patients who participate in structured dance might improve their balance, gait, and physical activity level.

Dance therapy was integrated into a 3-day intensive multidisciplinary social cognitive wellness program for individuals with MS in the Netherlands (Can Do Treatment, inspired from the CAN DO MS program in the United States). Preliminary efficacy data showed improved self-efficacy, as well as physical and mental health-related quality of life, but the specific effects of the dance intervention cannot be teased out. ${ }^{31}$

\section{Music therapy}

Several studies reported on the effects of music, or MT, in patients with chronic neurological conditions such as stroke, Parkinson's disease, Huntington's disease, and traumatic brain injury. MT interventions include singing, playing instruments, improvisation, making music, music listening, rhythmic entrainment, rhythmic auditory stimulation (RAS), song choice, sharing meaningful songs, musical autobiographies, musical life review, music mnemonics, recording music, musical identity, movement to music, and overall engagement with music. ${ }^{32-43}$ Approaches have included Nordoff Robbins, neurologic MT (neuro-MT), psychodynamic MT, and cognitive behavioral therapy. ${ }^{8,33,37,39,40,44,45}$ The goals of MT may include improving emotional status (adjustment to illness, mood states, expression of emotions), and enhancing neurologic performance (gait, 


\begin{tabular}{|c|c|c|c|c|c|c|c|}
\hline Publication & Intervention & $\begin{array}{l}\text { Type of study/ } \\
\text { article }\end{array}$ & $\begin{array}{l}\text { Setting/ } \\
\text { population }\end{array}$ & $\begin{array}{l}\text { Demographic } \\
\text { and MS } \\
\text { information }\end{array}$ & $\begin{array}{l}\text { Session } \\
\text { number/length }\end{array}$ & $\begin{array}{l}\text { Outcome measures - change } \\
\text { (when applicable) }\end{array}$ & Summary of findings \\
\hline $\begin{array}{l}\text { Mandelbaum, } \\
\text { et al. }{ }^{28} \\
(2016)\end{array}$ & Dance & $\begin{array}{l}\text { Uncontrolled } \\
\text { pilot study } \\
(n=8)\end{array}$ & Dance class & $\begin{array}{l}5 \mathrm{~F}, 4 \mathrm{M} \text {; age } \\
\text { range } 29-63 \\
\text { years (average } \\
49.5 \text { years); } \\
\text { PDDS scores } \\
0=2 \mathrm{~F}, 1 \mathrm{M} \\
1=2 \mathrm{~F}, 1 \mathrm{M} \\
3=1 \mathrm{~F}, 1 \mathrm{M}\end{array}$ & $\begin{array}{l}\text { Two 1-hour } \\
\text { sessions } \\
\text { weekly for } \\
4 \text { weeks }\end{array}$ & $\begin{array}{l}\text { TUG test - statistically significant } \\
\text { improvement ( } p<0.05) \\
\text { DGI - statistically significant } \\
\text { improvement ( } p<0.10) \\
\text { Activities-Specific Balance } \\
\text { Confidence Scale - statistically } \\
\text { significant improvement ( } p<0.10 \text { ) } \\
\text { Godin Leisure Time Questionnaire } \\
\text { - statistically significant } \\
\text { improvement ( } p<0.05 \text { post- } \\
\text { treatment; } p<0.10 \text { at } 3 \text { month } \\
\text { follow-up) } \\
\text { Significant improvement on DGI, } \\
\text { TUG, and MS Walking Scale-12 at } \\
\text { 3-month follow-up (each } p<0.05 \text { ) }\end{array}$ & $\begin{array}{l}\text { Patients with MS who participate in } \\
\text { dance may have improved balance, } \\
\text { gait, and physical activity. }\end{array}$ \\
\hline $\begin{array}{l}\text { Salgado and } \\
\text { de Paula } \\
\text { Vasconcelos } \\
\text { (2010) }\end{array}$ & $\begin{array}{l}\text { Physical } \\
\text { therapy } \\
\text { emphasizing } \\
\text { dance }\end{array}$ & $\begin{array}{l}\text { Case study } \\
(n=1)\end{array}$ & $\begin{array}{l}\text { Physical } \\
\text { therapy }\end{array}$ & $\begin{array}{l}1 \text { F; 45-years- } \\
\text { old; relapsing- } \\
\text { remitting MS } \\
\text { diagnosed } 10 \\
\text { years earlier }\end{array}$ & $\begin{array}{l}\text { Two 1-hour } \\
\text { and 40-minute } \\
\text { sessions } \\
\text { weekly for } \\
5 \text { months }\end{array}$ & $\begin{array}{l}\text { MRD improved from } 6 \text { to } 5 \\
\text { NRS improved from } 64 \text { to } 71 \\
\text { EDSS improved from } 3 \text { to } 2\end{array}$ & $\begin{array}{l}\text { Improved balance control, postural } \\
\text { control physical functioning and } \\
\text { ability to complete activities of } \\
\text { daily living noted; and patient } \\
\text { stated her self-esteem and } \\
\text { emotional state improved. }\end{array}$ \\
\hline
\end{tabular}

DGI = Dynamic Gait Index; EDSS = Expanded Disability Status Scale; $F=$ female; $M=$ male; $M R D=$ Minimal Record of Disability; $M S=$ multiple sclerosis; NRS = Scripps Neurological Rating Scale; PDDS = Patient-Determined Disease Steps; TUG = Timed Up and Go. 'Significant' refers to statistical significance.

speech, cognitive function), thereby facilitating activities of daily living and improving quality of life. $32,33,35,39-42$

Neuro-MT was shown to be effective in the sensorimotor and cognitive rehabilitation of individuals with neurological disorders; ${ }^{46}$ in many cases the music therapist works in conjunction with the rehabilitation team, particularly the physical therapist or occupational therapist. ${ }^{39,43}$ NeuroMT techniques encompass the use of: rhythmic entrainment to help with motor synchronization (RAS); rhythmic speech cueing to assist with speech production, fluency, and intelligibility; respiratory and oral motor exercises to assist with lung function, communication, and respiratory muscle strength; executive function training through music to assist with problem solving, decision making, organizing, sequencing, and planning; singing to assist with word recall; and music mnemonics to assist with memory challenges and learning. ${ }^{8,33,34,39,40,47,48}$ The proposed mechanism for the effects of MT on neurologic function is promotion of central neuroplasticity.

Few MT studies are specifically focused on MS (Table 3), but these include several randomized controlled trials (RCTS). Aldridge et al. randomized 20 patients with MS to MT (using the Nordoff Robbins approach) or no intervention (10 participants in each group). ${ }^{37}$ Active treatment consisted of 8-10 MT sessions over the course of a year, and assessments were conducted at baseline, every 3 months during the treatment period, and 6 months after treatment. Although there was no statistically significant difference between the control group and the MT group, there was a medium between-group effect size for measures of anxiety, depression, and self-esteem. Significant within-group improvement was noted on the same parameters for the MT group. Fatigue, anxiety, and self-esteem scores worsened after treatment in the MT group.
Conklyn et al. compared a 2-week home-based walking program (HBWP) utilizing RAS to no intervention, in 10 individuals with MS and gait disturbance. ${ }^{44}$ The HBWP involved walking for a total of 20 minutes daily for 2 weeks, with RAS music at a tempo 10\% above the participant's spontaneous walking cadence. There was a significant between-group difference for double support time favoring active treatment, and medium to large between-group effect sizes were noted for other gait parameters. Participants expressed high satisfaction with the RAS-based walking program.

Improved perceived functional use of the hand (ABILHAND questionnaire) was reported in a RCT of keyboard playing (with versus without audio feedback) in an inpatient setting. There was also a significant time effect for hand function and pinch strength tests. ${ }^{32}$ In a pilot RCT of MT versus music appreciation sessions to improve respiratory muscle strength in individuals with advanced MS, no significant between-group differences were noted, although there was improvement of expiratory muscle strength in the MT group contrasting with deterioration in the control group. ${ }^{47}$ Moore et al. compared learning via speech with learning through music on a recognition memory task, and their findings suggest that music mnemonics may help less impaired patients. ${ }^{34}$

One case study reported on a woman with MS in her thirties who used song-writing to gain insight and delve into her personal problems. ${ }^{49}$ When she first started participating in MT she exhibited a self-defeating mindset, but after engaging in $10 \mathrm{MT}$ sessions she was able to express her feelings and engage in self-disclosure, performed and recorded her song, and improved her self-esteem.

Qualitative studies have shed light on the perceptions of individuals with MS who experienced MT. Magee and Davidson, utilizing grounded 
Table 3: Studies about music and multiple sclerosis

\begin{tabular}{|c|c|c|c|c|c|c|c|}
\hline Publication & Intervention & $\begin{array}{l}\text { Type of study/ } \\
\text { article }\end{array}$ & $\begin{array}{l}\text { Setting/ } \\
\text { population }\end{array}$ & $\begin{array}{l}\text { Demographic } \\
\text { and MS } \\
\text { information }\end{array}$ & $\begin{array}{l}\text { Session } \\
\text { number/length }\end{array}$ & $\begin{array}{l}\text { Outcome measures - change } \\
\text { (when applicable) }\end{array}$ & Summary of findings \\
\hline $\begin{array}{l}\text { Gatti et al. }{ }^{32} \\
(2015)\end{array}$ & Music & $\begin{array}{l}\text { RCT } \\
(n=19)\end{array}$ & $\begin{array}{l}\text { Inpatient } \\
\text { hospital }\end{array}$ & $\begin{array}{l}12 \mathrm{~F}, 7 \mathrm{M} ; \\
\text { average age: } \\
46 \pm 9 \text { years; } \\
\text { primary or } \\
\text { secondary } \\
\text { progressive Ms; } \\
\text { Mean Functional } \\
\text { Independence } \\
\text { Measure score: } \\
103 \pm 14.7\end{array}$ & $\begin{array}{l}5 \text { days a week, } \\
30 \text { minutes a } \\
\text { day for } 3 \text { weeks }\end{array}$ & $\begin{array}{l}\text { ABILHAND questionnaire } \\
\text { - significant time } x \text { group } \\
\text { interaction favoring music } \\
(p<0.05) \\
\text { 9HPT - significant time effect for } \\
\text { both groups ( } p<0.05) \\
\text { Pinch dynamometer - significant } \\
\text { time effect for both groups } \\
(p<0.05) \\
\text { Jamar dynamometer - no } \\
\text { significant effect }\end{array}$ & $\begin{array}{l}\text { Patients with MS seemed to } \\
\text { improve their functional hand use } \\
\text { by playing a musical keyboard. }\end{array}$ \\
\hline $\begin{array}{l}\text { Conklyn } \\
\text { et al. }{ }^{44} \\
(2010)\end{array}$ & $\begin{array}{l}\text { MT } \\
\text { (home- } \\
\text { based } \\
\text { walking } \\
\text { program } \\
\text { with RAS) } \\
\text { versus no } \\
\text { intervention }\end{array}$ & $\begin{array}{l}\text { RCT }(n=10, \\
5 \text { MT and } \\
5 \text { controls) }\end{array}$ & $\begin{array}{l}\text { Outpatient MS/ } \\
\text { neurology clinic }\end{array}$ & $\begin{array}{l}7 \text { F, } 3 \text { M; average } \\
\text { age: MT group } \\
47 \pm 10.5 \text { years, } \\
\text { control group } \\
50.2 \pm 5.4 \text { years; } \\
\text { average disease } \\
\text { duration: } \\
\text { MT group } \\
16.6 \pm 10.4 \text { years, } \\
\text { control group } \\
12.2 \pm 5.7 \text { years; } \\
\text { Ambulation } \\
\text { Index: MT group } \\
4.4 \pm 0.5 \\
\text { control group } \\
5.3 \pm 0.5\end{array}$ & $\begin{array}{l}\text { MT group } \\
\text { received RAS } \\
\text { daily for } 4 \\
\text { weeks; control } \\
\text { group received } \\
\text { no intervention } \\
\text { for } 2 \text { weeks } \\
\text { then RAS for } \\
2 \text { weeks } \\
\text { Assessments at } \\
\text { baseline, 1, 2, 3, } \\
\text { and } 6 \text { weeks }\end{array}$ & $\begin{array}{l}\text { GAITRite System - statistically } \\
\text { significant improvement in } \\
\text { double support time in MT } \\
\text { group versus control group } \\
\text { ( } \mathrm{p}=0.0176 \text { left side and } \mathrm{p}=0.0247 \\
\text { right side); medium to high } \\
\text { effect sizes for between-group } \\
\text { differences in change for most } \\
\text { other gait parameters } \\
\text { Satisfaction survey - high } \\
\text { satisfaction level }\end{array}$ & $\begin{array}{l}\text { Feasibility and safety of RAS- } \\
\text { based home walking program } \\
\text { were demonstrated. } \\
\text { Potential benefit of RAS for } \\
\text { improving gait parameters. }\end{array}$ \\
\hline $\begin{array}{l}\text { Moore et al. }{ }^{34} \\
(2008)\end{array}$ & $\begin{array}{l}\text { MT (learning } \\
\text { via speech } \\
\text { versus } \\
\text { learning } \\
\text { through } \\
\text { music) }\end{array}$ & RCT $(n=38)$ & $\begin{array}{l}\text { Individuals } \\
\text { with MS }\end{array}$ & $\begin{array}{l}30 \text { F, } 30 \mathrm{M} \text {; } \\
\text { average age } \\
53.3 \text { years for } \\
\text { the spoken } \\
\text { group and } 50.3 \\
\text { years for the } \\
\text { music group; } \\
\text { EDSS score } \\
\text { range } 3.5-7\end{array}$ & One session & $\begin{array}{l}\text { EDSS, Buschke's SRT, WCST } \\
\text { Logical Memory I, subset from } \\
\text { WMS-III), Yes-No Recognition } \\
\text { Test, subset of Rey's AVLT, } \\
\text { Seashore Rhythm Test } \\
\text { No significant difference } \\
\text { on any tests between MT } \\
\text { group and spoken group on } \\
\text { recognition tasks or baseline } \\
\text { neuropsychological functioning } \\
\text { (p>0.05) }\end{array}$ & $\begin{array}{l}\text { Correlation analyses suggested } \\
\text { music mnemonics may assist } \\
\text { learning in individuals with less } \\
\text { impairments. }\end{array}$ \\
\hline $\begin{array}{l}\text { Aldridge et } \\
\text { al. }^{37} \\
(2005)\end{array}$ & MT & RCT $(n=20)$ & $\begin{array}{l}\text { Music therapy } \\
\text { sessions }\end{array}$ & $\begin{array}{l}14 \mathrm{~F}, 6 \mathrm{M} \text {; age } \\
\text { range 29-47 } \\
\text { years; relapsing, } \\
\text { primary and } \\
\text { secondary } \\
\text { progressive } \\
\text { MS; average } \\
\text { time since } \\
\text { diagnosis } 11 \\
\text { years; average } \\
\text { EDSS } 2.6\end{array}$ & $\begin{array}{l}\text { 8-10 sessions } \\
\text { over } 1 \text { year } \\
\text { (three blocks of } \\
\text { single sessions) }\end{array}$ & $\begin{array}{l}\text { EDSS, HADS, BDI, HAQUAMS, } \\
\text { SESA (each p>0.05 with } \\
\text { exception of HAQUAMS, p=0.07) } \\
\text { No significant difference } \\
\text { between control and MT group, } \\
\text { but medium effect size for } \\
\text { anxiety, depression, and self- } \\
\text { esteem. Significant within-group } \\
\text { improvement in the MT group } \\
\text { for depression, self-esteem, } \\
\text { and anxiety. Worsening of self- } \\
\text { esteem, anxiety, and fatigue in } \\
\text { MT group at follow-up }\end{array}$ & $\begin{array}{l}\text { Individuals who participated in } \\
\text { music therapy demonstrated } \\
\text { improved fatigue, mood, and } \\
\text { self-acceptance. It is possible that } \\
\text { the scales worsened at follow-up } \\
\text { because the music therapy was } \\
\text { removed. }\end{array}$ \\
\hline
\end{tabular}


Table 3: Cont.

\begin{tabular}{|c|c|c|c|c|c|c|c|}
\hline Publication & Intervention & $\begin{array}{l}\text { Type of study/ } \\
\text { article }\end{array}$ & $\begin{array}{l}\text { Setting/ } \\
\text { population }\end{array}$ & $\begin{array}{l}\text { Demographic } \\
\text { and MS } \\
\text { information }\end{array}$ & $\begin{array}{l}\text { Session } \\
\text { number/length }\end{array}$ & $\begin{array}{l}\text { Outcome measures - change } \\
\text { (when applicable) }\end{array}$ & Summary of findings \\
\hline $\begin{array}{l}\text { Schmid7 } \\
\text { (2006) } \\
\text { Schmid }^{36} \\
\text { (2005) } \\
\text { Schmid and } \\
\text { Aldridge } \\
\text { (2004) }\end{array}$ & MT & RCT $(n=20)$ & $\begin{array}{l}\text { Patients with } \\
\text { MS }\end{array}$ & $\begin{array}{l}14 \mathrm{~F}, 6 \mathrm{M} \text {; age } \\
\text { range } 29-47 \\
\text { years; average } \\
\text { duration of } \\
\text { disease } 11 \text { years }\end{array}$ & $\begin{array}{l}\text { Three blocks of } \\
8-10 \text { sessions } \\
\text { per year }\end{array}$ & $\begin{array}{l}\text { EDSS, MSFC, HADS, BDI, } \\
\text { HAQUAMS, SESA } \\
\text { Qualitative analysis: therapeutic } \\
\text { narrative analysis and repertory } \\
\text { grid method to review videos, } \\
\text { music therapy interview } \\
\text { No significant difference } \\
\text { (p>0.05) between the control } \\
\text { and MT groups from baseline to } \\
\text { one year } \\
\text { Within-group improvement } \\
\text { (p<0.05) in MT group for } \\
\text { anxiety, depression, and } \\
\text { self-acceptance; minimal } \\
\text { improvement in communication } \\
\text { subscale of HAQUAMS } \\
\text { No recognizable changes in } \\
\text { functional or motor skills in } \\
\text { either group }\end{array}$ & $\begin{array}{l}\text { MT was found to be valuable } \\
\text { in relief of emotional burden, } \\
\text { increasing personal activity, } \\
\text { improving well-being, and } \\
\text { increasing positive self-identity } \\
\text { and self-confidence. } \\
\text { Increased coping, creativity, } \\
\text { understanding of patient needs, } \\
\text { self-image, personal experience } \\
\text { perspective, social relationships; } \\
\text { importance of not focusing on } \\
\text { symptoms but on resources and } \\
\text { abilities. } \\
\text { Due to the stigmatizing effects } \\
\text { of having MS, and the positive } \\
\text { effects of MT, it is important to } \\
\text { take aesthetics into consideration } \\
\text { when assessing clinical } \\
\text { improvement. }\end{array}$ \\
\hline $\begin{array}{l}\text { Wiens et al. } .^{47} \\
\text { (1999) }\end{array}$ & MT & $\begin{array}{l}\text { Pilot RCT } \\
(n=19)\end{array}$ & $\begin{array}{l}\text { Long-term care } \\
\text { center }\end{array}$ & $\begin{array}{l}\text { Predominantly } \\
\text { female } \\
\text { participants; } \\
\text { age range } \\
\text { 37-68 years; } \\
\text { advanced MS } \\
\text { with average } \\
\text { EDSS score } 8.3\end{array}$ & $\begin{array}{l}\text { Three } 30 \\
\text { minute } \\
\text { sessions per } \\
\text { week for } 12 \\
\text { weeks }\end{array}$ & $\begin{array}{l}\text { Mouth-pressure testing } \\
\text { (inspiratory and expiratory) } \\
\text { No statistically significant } \\
\text { results; MT group demonstrated } \\
\text { improved expiratory muscle } \\
\text { strength; control group } \\
\text { demonstrated deterioration }\end{array}$ & $\begin{array}{l}\text { It is imperative that interventions } \\
\text { need to begin early on in the } \\
\text { disease process. }\end{array}$ \\
\hline $\begin{array}{l}\text { Magee and } \\
\text { Davidson }{ }^{41} \\
\text { (2002) }\end{array}$ & MT & $\begin{array}{l}\text { Uncontrolled } \\
\text { pilot study } \\
(n=14)\end{array}$ & $\begin{array}{l}\text { Day care and } \\
\text { residential } \\
\text { facility for } \\
\text { complex neuro- } \\
\text { disabilities }\end{array}$ & $\begin{array}{l}\text { No demographic } \\
\text { information } \\
\text { provided; } \\
\text { five of the } 14 \\
\text { participants } \\
\text { were diagnosed } \\
\text { with MS }\end{array}$ & $\begin{array}{l}\text { One weekly } \\
\text { session for } \\
2 \text { weeks }\end{array}$ & $\begin{array}{l}\text { POMS-BI form } \\
\text { Significant change in positive } \\
\text { direction in agreeable-hostile } \\
\text { ( } p=0.003) \text {, energetic-tired } \\
(p=0.05) \text {, and composed-anxious } \\
\text { ( } p=0.01 \text { ) mood states pre- and } \\
\text { post-MT; no significant results } \\
\text { for elated-depressed mood } \\
\text { subscale }\end{array}$ & $\begin{array}{l}\text { MT may be effective in addressing } \\
\text { negative mood states in patients } \\
\text { undergoing neuro-rehabilitation. }\end{array}$ \\
\hline
\end{tabular}


Table 3: Cont.

\begin{tabular}{|c|c|c|c|c|c|c|c|}
\hline Publication & Intervention & $\begin{array}{l}\text { Type of study/ } \\
\text { article }\end{array}$ & $\begin{array}{l}\text { Setting/ } \\
\text { population }\end{array}$ & $\begin{array}{l}\text { Demographic } \\
\text { and MS } \\
\text { information }\end{array}$ & $\begin{array}{l}\text { Session } \\
\text { number/length }\end{array}$ & $\begin{array}{l}\text { Outcome measures - change } \\
\text { (when applicable) }\end{array}$ & Summary of findings \\
\hline $\begin{array}{l}\text { McNab } \\
(2010)\end{array}$ & MT & $\begin{array}{l}\text { Article and } \\
\text { case vignettes } \\
(\mathrm{n}=2)\end{array}$ & $\begin{array}{l}\text { Home-based } \\
\text { services: } \\
\text { neuro-palliative } \\
\text { care }\end{array}$ & $\begin{array}{l}1 \mathrm{~F} \text { in her early } \\
60 \mathrm{~s} \text { (motor } \\
\text { neuron disease); } \\
1 \mathrm{~F} \text { in her mid- } \\
\text { 70s (progressive } \\
\text { MS and EDSS } \\
\text { score 8.5) }\end{array}$ & $\begin{array}{l}\text { Multiple } \\
\text { sessions over } \\
\text { several months } \\
\text { (first case); or } \\
\text { years (second } \\
\text { case) }\end{array}$ & N/A & $\begin{array}{l}\text { Described use of music therapy } \\
\text { with individuals with progressive } \\
\text { neurological diseases; included } \\
\text { two case vignettes; proposed that } \\
\text { music therapy enhances QoL and } \\
\text { coping. }\end{array}$ \\
\hline $\begin{array}{l}\text { Lee }^{49} \\
(2007)\end{array}$ & MT & $\begin{array}{l}\text { Case study } \\
(n=1)\end{array}$ & $\begin{array}{l}\text { Long-term care } \\
\text { facility }\end{array}$ & $\begin{array}{l}\text { 1F in her 30s; } \\
\text { diagnosed with } \\
\text { MS in early } \\
\text { adolescence }\end{array}$ & $\begin{array}{l}10 \text { weekly } \\
\text { sessions }\end{array}$ & N/A & $\begin{array}{l}\text { Song-writing used with a woman } \\
\text { with MS in order to develop } \\
\text { insight into her situation and } \\
\text { explore personal issues. }\end{array}$ \\
\hline $\begin{array}{l}\text { Steele }^{4} \\
(2005)\end{array}$ & MT & $\begin{array}{l}\text { Case series } \\
(n=3)\end{array}$ & $\begin{array}{l}\text { Inpatient } \\
\text { neurology ward }\end{array}$ & $\begin{array}{l}\text { \#1: 39-year-old F, } \\
\text { EDSS score } 9 \\
\text { \#2: 35-year-old } \\
\text { F, EDSS score } \\
\text { between 8-8.5 } \\
\text { \#3: 52-year-old F, } \\
\text { EDSS score } 8.5 \\
\text { All secondary } \\
\text { progressive MS }\end{array}$ & Not reported & N/A & $\begin{array}{l}\text { MT assisted with coping } \\
\text { strategies, sense of self, and sense } \\
\text { of control. }\end{array}$ \\
\hline $\begin{array}{l}\text { Magee and } \\
\text { Davidson }{ }^{42} \\
\text { (2004) }\end{array}$ & MT & $\begin{array}{l}\text { Systematic } \\
\text { qualitative } \\
\text { analysis of } \\
\text { individual case } \\
\text { studies }(n=6)\end{array}$ & $\begin{array}{l}\text { Day care } \\
\text { residential } \\
\text { facility for } \\
\text { complex neuro- } \\
\text { disabilities }\end{array}$ & $\begin{array}{l}4 \mathrm{~F}, 2 \mathrm{M} \text {; age } \\
\text { range } 31-59 \\
\text { years; chronic } \\
\text { progressive } \\
\text { MS; time since } \\
\text { diagnosis: range } \\
\text { 3-25 years }\end{array}$ & $\begin{array}{l}\text { Weekly } \\
45 \text {-minute } \\
\text { sessions } \\
\text { for around } \\
6 \text { months } \\
\text { (average } 18 \\
\text { sessions) }\end{array}$ & Grounded theory & $\begin{array}{l}\text { Music therapy affects expressive } \\
\text { and interpersonal self, physical, } \\
\text { and emotional challenges of living } \\
\text { with an acquired disability. }\end{array}$ \\
\hline
\end{tabular}

9HPT = 9-Hole Peg Test; $A V L T=$ Auditory-Verbal Learning Test; BDI = Beck Depression Inventory; EDSS = Expanded Disability Status Scale; F = female; HADS = Hospital Anxiety and

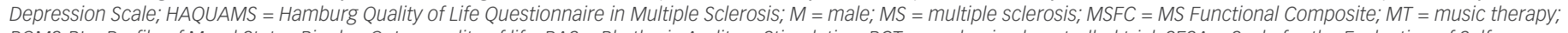
POMS-BI = Profile of Mood States Bipolar; $Q O L=$ quality of life; RAS = Rhythmic Auditory Stimulation; $R C T=$ randomized controlled trial; SESA = SCale for the Evaluation of SelfAcceptance; SRT = Selective Reminding Task; WCST = Wisconsin Card Sorting Test; WMS-III = Weschler Memory Scale - 3rd edition. 'Significant' refers to statistical significance.

theory, identified three main themes in six individuals with progressive MS: ways of coping with emotions, the experience of participating in MT, and the experience of living with MS. ${ }^{42}$ Moreira et al. asked eight patients to identify 10 to 15 preferred songs that were significant in their lives, then conducted interviews which were analyzed, utilizing Even Ruud categories. ${ }^{35}$ The authors found that recalling these preferred songs activated the participants' affective memories; improved their body perception, feelings, and identities; enabled them to express themselves; and provided them with a coping strategy for living with MS. ${ }^{35}$

\section{Summary and conclusions}

This narrative review highlights the breadth of therapeutic art interventions that can be offered to individuals with MS, at every stage of the disease and in a variety of settings (inpatient versus outpatient, group versus individual sessions), with a wide range of emotional and physical outcomes. These interventions are accessible to all; although, adaptations may be needed to accommodate for physical or cognitive impairment. The choice of activity is usually preference-based, fostering patient empowerment and self-efficacy, which may result in higher motivation and better long-term adherence, compared to more traditional interventions. Therapeutic art professionals provide a supportive environment, focus on the person, not the disability, and offer a success-oriented experience.,33 Finally, art-based therapies can be used in combination with traditional interventions such as physical or occupational therapy.

Our review also demonstrates the paucity of evidence regarding the effects of therapeutic art interventions in MS, particularly for art and D/MT. Sample sizes are often small, and few studies include followup assessments after the intervention is completed. In addition, many studies have been conducted in clinical settings, while the majority of individuals with MS are community-dwelling. Access to a therapeutic arts professional may be limited by many factors, including distance and cost, therefore the long-term pursuit of arts-based activities initiated under the guidance of a skilled and qualified professional should be assessed. Investigation of the mechanism of action of arts-based interventions, particularly neuroplasticity, is lacking in MS. All of these evidence gaps constitute opportunities for future research on therapeutic arts interventions in MS. $\square$ 
1. Fox RJ, Bethoux F, Goldman MD, Cohen JA, Multiple sclerosis: advances in understanding, diagnosing, and treating the underlying disease, Cleve Clin J Med, 2005;73:91-102.

2. Marrie RA, Comorbidity in multiple sclerosis: implications for patient care, Nat Rev Neurol, 2017;13:375-82.

3. Newsome SD, Aliotta PJ, Bainbridge J, et al., A framework of care in multiple sclerosis, part 2, Int J MS Care, 2017;19:42-56

4. Steele M, Coping with multiple sclerosis: a music therapy viewpoint, Aust J Music Ther, 2005;16:70-87.

5. Fraser $\mathrm{C}$, Keating $\mathrm{M}$, The effect of a creative art program on self-esteem, hope, perceived social support, and self-efficacy in individuals with multiple sclerosis: a pilot study, J Neuropsi Nurs, 2014;46:330-36.

6. Ostermann T, Schmid W, Music therapy in the treatment of multiple sclerosis: a comprehensive literature review, Expert Rev Neurother, 2006;6:469-77.

7. Schmid W, Maintaining dialogue: active music therapy for people living with multiple sclerosis, Music Ther Today (online), 2006;8:77-98. Available at: http://musictherapyworld.net (accessed February 2, 2017).

8. Walker ID, Gonzalez EW, Review of intervention studies on depression in persons with multiple sclerosis, Issues Ment Health Nurs, 2007:28:511-31.

9. National MS Society, Multiple sclerosis: just the facts, 2016 Available at: www.nationalmssociety.org/NationalMSSociety/ media/MSNationalFiles/Brochures/Brochure-Just-the-Facts.pdf (accessed May 2, 2017).

10. Patti F, Nicoletti A, Messina S, et al., Prevalence and incidence of cognitive impairment in multiple sclerosis: a population-based survey in Catania, Sicily, J Neurol, 2015;262:923-30.

11. Scott JA, Suicidal thoughts not uncommon in MS, Everyday Health, 2015. Available at: www.everydayhealth.com/multiplesclerosis/symptoms/suicidal-thoughts-not-uncommon-ms (accessed May 2, 2017).

12. National MS Society, Depression, 2016. Available at: www. nationalmssociety.org/Symptoms-Diagnosis/MS-Symptoms/ Depression (accessed May 2, 2017)

13. Esmonde L, Long AF, Complementary therapy use by persons with multiple sclerosis: benefits and research priorities, Complement Ther Clin Pract, 2008; 14:176-84.

14. Namjooyan F, Ghanavati R, Majdinasab N, et al., Uses of complementary and alternative medicine in multiple sclerosis, J Tradit Complement Med, 2014;4:145-52

15. Sacks O, Musicophilia: Tales of Music and the Brain, Revised and Expanded Edition, New York, NY: Knopf Doubleday Publishing Group, 2008.

16. American Art Therapy Association (AATA), What is art therapy? Available at: https://arttherapy.org/aata-aboutus/ (accessed April 10, 2017).

17. American Dance Therapy Association (ADTA), What is dance/ movement therapy? Available at http://adta.org/faqs (accessed April 7, 2017).

18. American Music Therapy Association (AMTA), What is music therapy? Available at: www.musictherapy.org (accessed April 10, 2017).

19. National MS Society, Readers report on MS and art, Momentum, 2013;Spring:3. Available at: www.nationalmssociety.org/ NationalMSSociety/media/MSNationalFiles/Documents/ NationalMSSociety/media/MSNationalFlles/Documen August 9, 2017).

20. Zagieboylo C, Making your life with MS a work of art, Momentum 2013;Summer:66. Available at: www.nationalmssociety.org/ NationalMSSociety/media/MSNationalFiles/Documents/ Momentum/Momentum_Summer_2013.pdf (accessed August 9, 2017)

21. Uhland V, The picture of health, Momentum, 2013:Summer:42. Available at: www.nationalmssociety.org/NationalMSSociety/ media/MSNationalFiles/Documents/Momentum/Momentum Summer_2013.pdf (accessed August 9, 2017).

22. Kelly NA, The use of visual art for stress relief: a case report of newly diagnosed multiple sclerosis, EXPLORE, 2009;5:167-70.

23. Hunt L, Nikopoulou-Smyrni P, Reynolds F, "It gave me something big in my life to wonder and think about which took over the space... and not MS": Managing well-being in multiple sclerosis through art-making Disabil Rehabil, 2014:36:1139-47.

24. Sutherland JI, Art therapy with a woman who has multiple medica conditions, Am J Art Ther, 1999;37:84-98.

25. Field J, Art therapy in a neurological hospital in London, Am J Art Ther, 1976;15:99-103.

26. Stutsman D, Thomas FP, Ballard R, Healing power of art therapy for multiple sclerosis patients, Int J MS Care, 2008;10(Suppl. 1):52

27. Shanahan J, Morris ME, Bhriain ON, et al., Dance for people with Parkinson disease: what is the evidence telling us? Arch Phys Med Rehabil, 2015:96:141-53.

28. Mandelbaum R, Triche EW, Fasoli SE, LO AC, A pilot study: examining the effects and tolerability of structured dance intervention for individuals with multiple sclerosis, Disabil Rehabil, 2016;38:218-22.

29. Westheimer O, McRae C, Henchcliffe C, et al., Dance for PD: a preliminary investigation of effects on motor function and quality of life among persons with Parkinson's disease (PD), J Neural Transm (Vienna), 2015:122:1263-70.

30. Salgado $R$, de Paula Vasconcelos LA, The use of dance in the rehabilitation of a patient with multiple sclerosis, Am J Dance Ther, 2010;32:53-63.

31. Jongen PJ, Heerings $M$, Ruimschotel R, et al., An intensive social cognitive program (can do treatment) in people with relapsing remitting multiple sclerosis and low disability: a randomized controlled trial protocol, BMC Neurol, 2016:16:81.

32. Gatti R, Tettamanti A, Lambiase $\mathrm{S}$, et al., Improving hand function use in subjects with multiple sclerosis using a musical keyboard: a randomized controlled trial, Physiother Res Int, 2015;20:100-7.

33. MCNab E, Music therapy in progressive neurological disease: a neuropalliative rehabilitation perspective, Aust J Music Ther 2010;21:59-76.

34. Moore KS, Peterson DA, O'Shea G, et al., The effectiveness of music as a mnemonic device on recognition memory for people with multiple sclerosis, J Music Ther, 2008;45:307-29.

35. Moreira SV, França CC, Moreira MA, Lana-Peixoto MA, Musical identity of patients with multiple sclerosis, Arg Neuropsiquiatr. 2009:67:46-9.

36. Schmid W, "Swing in my brain": active music therapy for people living with multiple sclerosis. In: Aldridge D (ed), Music Therapy \& Neurological Rehabilitation: Performing Health, London: Jessica Kingsley Publishers, 2005;161-88.

37. Aldridge D, Schmid W, Kaeder M, Schmidt C, Ostermann, T, Functionality or aesthetics? A pilot study of music therapy in the treatment of multiple sclerosis patients, Complement Ther Med 2005;13:25-33.

38. M Pothoulaki, R MacDonald, The use of music in chronic illness: evidence and arguments. In: MacDonald R, Kreutz G, and Mitchell $\mathrm{L}$ (eds), Music, Health, and Wellbeing, New York: Oxford University Press, 2012;239-56.

39. AB LaGasse, MH Thaut, Music and rehabilitation: neurological approaches. In: MacDonald R, Kreutz G, Mitchell L (eds), Music, Health, and Wellbeing, New York: Oxford University Press, 2012;153-63.

40. LaGasse $A B$, Thaut $M H$, The neurobiological foundation of neurologic music therapy, Music Med, 2013;5:228-33.

41. Magee WL, Davidson JW, The effect of music therapy on mood states in neurological patients: a pilot study, J Music Ther 2002;39:20-9

42. Magee WL, Davidson JW, Music therapy in multiple sclerosis: results of a systematic qualitative analysis, Music Ther Perspect, 2004;22:39-51.

43. Weller $\mathrm{CM}$, Baker FA, The role of music therapy in physical rehabilitation: a systematic literature review, Nordic J Music Ther, 2011;20:43-61.

44. Conklyn D, Stough D, Novak E, et al., A home-based walking program using rhythmic auditory stimulation improves gait performance in patients with multiple sclerosis: a pilot study, Neurorehabil Neural Repair, 2010;24:835-42.

45. Schmid W, Aldridge D, Active music therapy in the treatment of multiple sclerosis patients: a matched control study, J Music Ther 2004;41:225-40.

46. Moumdjian L, Sarkamo T, Leone C, et al., Effectiveness of musicbased interventions on motricity or cognitive functioning in neurological populations: a systematic review, Eur J Phys Rehabil Med, 2017;53:466-82

47. Wiens ME, Reimber MA, Guyn HL, Music therapy as a treatment method for improving respiratory muscle strength in patients with advanced multiple sclerosis: a pilot study, Rehabil Nurs, 1999;24:74-80.

48. Thaut MH, Peterson DA, McIntosh GC, Temporal entrainment of cognitive functions: musical mnemonics induce brain plasticity and oscillatory synchrony in neural networks underlying memory, Ann NY Acad Sci, 2005;1060:243-54.

49. Lee J, Music therapy with a woman who was hurt by a cowboy, Canadian Journal of Music Therapy, 2007:13:30-7. 